\title{
Influence of Organizational Culture, Leadership Style and Work Motivation on Human Resource Development and Employee Performance at the Office of the Ministry of Religious Affairs of South Sulawesi Province
}

\author{
Musmulyadi $^{1}$, Abdul Rahman Mus ${ }^{2}$, Bahar Sinring $^{3}$, Baharuddin Semmaila $^{4}$ \\ ${ }^{1,2,3,4}$ University of Muslim Indonesia (UMI), Makassar, Indonesia
}

Corresponding Author: Musmulyadi

\begin{abstract}
This study aims to: (1) analyze the cultural influence of employee organization, in the form of integrity, professional, innovation, responsibility, and conscientiousness 2) analyze the influence of employee's work leadership style, in the form of spiritual leadership, autocratic style, laissez-fair style, and transformational style (3) analyze the influence of employee work motivation, the need for flexibility, the need to excel, the need for affiliation, and reward (4) analyze the influence of employee development, namely: benchmarking, learning tasks, intelligent quotient, and emotional quotient (5) analyzing leadership style influence on human resource development (6) analyzing the influence of motivation (7) analyzing organizational culture through human resource development (8) analyzing leadership style through human resource development affect employee performance. (9) analyzing motivation through the development of human resources affects the performance of employees (10) analyzing the development of human resources affects the performance of employees

The object of this research is employees of the Ministry of Religious Affairs of South Sulawesi which is divided into 24 Offices of the Ministry of Religious Affairs of The City Regency and 1 Regional Office. The sample of this study was 386 out of a population of 10,293 employees. The research sample was obtained by random sampling cluster technique after which the
\end{abstract}

population was proportionate using proportional random sampling. The data is analyzed with the Structural Equation Modelling (SEM) program. The results showed: (1) Organizational Culture has no effect on employee performance. (2) Leadership Style positively and significantly affects employee performance (3) Work Motivation positively and significantly affects employee performance (4) Work Motivation positively and significantly affects employee performance (5) Leadership style positively and significantly affects Human Resource Development (6) Leadership Style positively and significantly affects Human Resource Development. (7) Leadership Style has a positive and significant effect on Human Resource Development (8) Organizational Culture positively and significantly affects Performance Through Human Resource Development (9) Organizational Culture positively and significantly affects Performance Through Human Resource Development. (10) Organizational Culture has a positive and significant impact on Performance through Human Resource Development.

Keywords: Performance, Organizational Culture, Leadership Style, Work Motivation, Human Resources Development

\section{INTRODUCTION}

The condition of government in the era of regional autonomy in Indonesia has resulted in a paradigm shift of government implementation from the paradigm of 
Musmulyadi et.al. Influence of organizational culture, leadership style and work motivation on human resource development and employee performance at the office of the ministry of religious affairs of South Sulawesi Province.

centralization towards decentralization which is characterized by the granting of authority and broad responsibility to the region, so that each region with its potential has the opportunity to regulate and develop its potential. Every organization or institution will always be faced with various challenges or opportunities for internal and external changes of the organization colored by various developments / advances that expect to improve the quality of performance owned by employees or employees. The challenges faced in the era of globalization in various areas of organization or institutions are increasingly complex, namely the rapid progress and development of science and technology that demands increased productivity and employee performance by trying to develop the potential that each individual or group has in supporting the achievement of organizational goals and objectives that have been formulated.

In order to realize effective government management, the Office of the Ministry of Religious Affairs in South Suawesi Province as a vertical agency seeks to provide excellent government services to the community. Performance improvement continues to be improved, various efforts were made to improve the quality of special services to the people of South Sulawesi.

The phenomenon faced by the Ministry of Religious Affairs in South Sulawesi Province until now is still low quality of employees in serving the needs of the community related to community services. This is characterized by the low quality of human resources that are mostly obtained from graduates of general secondary education. This has an impact on the relatively low conceptual understanding and work capability of employees in developing government organizations, especially regarding their vision and mission.

Another phenomenon in the Ministry of Religious Affairs in South Sulawesi is the lack of motivation from the leadership to the performance of its employees so as to have an impact on the lack of maximum service related to services to the community, especially in the field of hajj and umrah. As a religious institution, the Ministry of Religious Affairs not only manages hajj and umrah but also manages various other fields such as Madrasah, Islamic educators, religious extension workers, and Islamic community organizations.

The next phenomenon that occurred in the Ministry of Religious Affairs of South Sulawesi Province related to leadership issues where the leadership has not been able to optimize the potential of the organization and has not been able to adjust to the demands of the external environment in this case meets the needs of the community because so far the leadership is generally shackled by the existing rules so that it lacks improvisation and innovation aimed at improving the welfare of the community and what happens leaders always rely on existing rules. The head of the Ministry of Religious Affairs office in South Sulawesi Province always relies on his formal authority so that power becomes a force in moving subordinates.

In the initial observations made by prospective researchers, the phenomenon found is also related to the problem of human resources gaps, this can be seen from several city districts that according to the observations of prospective researchers there are very prominent Human Resources and some are not. Departing from the phenomena faced by the Office of the Ministry of Religious Affairs of South Sulawesi Province which is a problem that must be faced and solved.

\section{LITERATUR REVIEW Performance}

Performance is a factor that must be known and informed to certain parties or interested parties to know the level of achievement of the results of an organization that is linked to the vision and mission carried out by an organization, and to know the positive and negative impacts of operational policies that have been set 
Musmulyadi et.al. Influence of organizational culture, leadership style and work motivation on human resource development and employee performance at the office of the ministry of religious affairs of South Sulawesi Province.

before. Employee performance is the result of quality and quantity of work that an employee achieves in carrying out the duties and responsibilities given to him (meutia, 2017).

Performance is an activity or activity performed by an individual that aims to achieve a set target. (Nazwirman, 2019). The target in question can be understood as an achievement achieved by a person or employee both in quality and quantity so that it can be known that the performance of employees has met the standards of needs and desires of an organization. Further explained by Rendyka and Djambur that the achievements achieved by employees are inseparable from the existence of management in creating job satisfaction, performance is the ability of a person to produce products or services to encourage the achievement of the desired goals. (Dio \&Hamid, 2017)

So that performance can be understood as an achievement achieved by a person for the things he has done both in the form of positive and negative results. The achievement of the performance of employees or subordinates is strongly influenced by the leadership and also greatly influences the development of an organization or the essence of both government and non-governmental institutions.

\section{Organizational Culture}

The use of the term organizational culture by referring to the prevailing culture in the company, because in general the company is in the form of an organization, namely cooperation between several ornagn who form a separate group or task force. Organizational culture can be defined as a system of values, beliefs, assumptions, or norms that have long been agreed upon and followed by members of an organization as a guideline for conduct and solving organizational problems (Sutrisno, 2018). Organizational culture is also called corporate culture, which is a set of values or norms that are relatively long in force, embraced jointly by members of the organization (Employees) as norms of behavior in solving organizational problems (companies). Organizational culture is a complex pattern of assumptions about the place and function of groups in the world, organizational culture is directly related to the effectiveness and performance of the organization, the stronger the organizational culture the more effective the organization (Lapisa, Kariza, \& Aramina, 2015). Organizational culture is directly connected to the effectiveness and performance of the organization the stronger the organizational culture, the more effective the organization will be. In fact, what is meant by organizational culture is a culture that becomes a reference in an organisation where there is a group of people who interact. Organizational culture can also be interpreted as a culture that is formed in accordance with the purpose of the organization by sharing things obtained by learning, and consists of all the values, activities, philosophies, ideals, etc. of an organization.

\section{Leadership}

Human resources have a very strategic position in the organization, meaning that the human element plays an important role in carrying out activities for the achievement of goals. In order to improve his human resources, in addition to improving his skills and knowledge, it is also very important that a leader in leading, mobilizing, directing and supervising his subordinates apply leadership style according to environmental situations and conditions, it could be that at any given moment a leader is needed using an authoritarian leadership style, at other times it is needed using participatory styles. Leadership is the ability of a person to influence another person or group of people toward achieving a previously mutually agreed organizational goal.

The leader is always trying to develop what he wants to do. A leader must always light a fire of trust in his 
Musmulyadi et.al. Influence of organizational culture, leadership style and work motivation on human resource development and employee performance at the office of the ministry of religious affairs of South Sulawesi Province.

subordinates by using a variety of leadership styles so that there is variation and motivation for his employees or subordinates. Because the behavior and actions of employees are strongly influenced by the leadership style of a leader. Leadership style has a positive and very significant impact on organizational culture, in addition leadership style also has a significant effect on employee loyalty, work motivation, while organizational culture has a significant impact on employee loyalty, and work motivation has a significant effect on employee loyalty. (Mochlas, 2017)

\section{Work Motivation}

The motivation of working people is various. There are people motivated to do something because the money is a lot, although sometimes the work is not legally correct. There are also motivated because of a sense of security or safety of work, and there are even people who are motivated because the work gives high prestige even though the salary is very small. Motivation comes from the Latin bahsa Movore which means motivation, desire, because, the reason someone does something. Motivation is a psychological motivation that leads and guides a person towards a tujan (Dafruddin \&Heryanto, 2019). Motivation is divided into two factors or commonly called motivators namely: Intrinsic motivation and extrinsic motivation.

Motivation works as a psychological process in a person that is influenced by internal and external factors. Internal factors that can influence the motivation of oneself include: The desire to be able to live, the desire to have, the desire to obtain worship, the desire to rule. While external factors that affect one's work motivation are; Working environment conditions, Adequate compensation, status and responsibility.

\section{Human Resource Development}

Human resources are very important in the organization, because with human resources in an organization that is well managed, will produce a potential human or a resilient organization in carrying out a variety of work activities that are reliable, independent and professional to facilitate the achievement of organizational goals.

Human resource development is an effort to eliminate the gap between the ability of employees and the desired organization. The effort is carried out through improving the work skills of employees by adding knowledge and skills and changing attitudes. Employees are the most valuable organizational wealth because with all their potential, employees can continue to be trained and developed, so that they can be more useful, their achievements become more optimal to achieve organizational goals.

There is a gap between the ability of employees and what the organization wants to cause the need for the organization to bridge the gap, one way is training and development. Thus it is expected that all the potential that employees have such as knowledge, skills and attitudes can be improved, eventually the gap is reduced or there is no longer a gap.

Human resource development (HR) is an effort made to form a qualified person and have skills, work skills, and loyalty to the company or organization. Human resource development aims to produce a logical and comprehensive related framework for developing an environment where employees are encouraged to learn and develop. Human resource development activities include traditional training programs, but the emphasis is more on developing intellectual capital and promoting learning, in which knowledge is systematically managed. Human resource development is also related to the planning approach to encourage or motivate selfdevelopment with adequate support and guidance from within the organization, aspirations and individual needs. Qualified Human Resources will help the company to further develop and achieve the company's goals, here are some things that can be 
Musmulyadi et.al. Influence of organizational culture, leadership style and work motivation on human resource development and employee performance at the office of the ministry of religious affairs of South Sulawesi Province.

accomplished in human resources development (Elbadiansyah, 2019).

\section{Behavior and Attitude Theory}

The theory of attitude and behaviour developed by (Triandis, 1971) is seen as an underlying theory to explain independence. The theory states, that behavior is determined for what people want to do (attitudes), what they think they will do (social rules), what they can do (habits) and with the consequences of the behavior they think. Attitudes concerning cognitive components are related to beliefs, while the affective attitude component has the connotation of likes or dislikes.

Attitude according to (Robbins, 2003, p. 93) is as an evaluative statement of an object, person, or event. Behavior is one component of attitude to behave in a certain way towards someone or something. Attitude and behavior theory is a theory that states that one's behavior is determined by attitudes, social rules, habits and knowing the consequences of such behavior. The theory of attitude and behavior wants to explain about the attitude that a person has determines one's behavior. Attitudes and behaviors are often said to be closely related. The results also showed a strong relationship between attitudes and behaviors (Ayuningtyas, Yulian, \&Pamudji, 2012).

\section{Attribution Theory}

Attribution theory studies the process of how a person interprets an event, and learns how to interpret the reason or cause of his behavior. Fritz Heider as the originator of attribution theory reveals that this theory explains a person's behavior on how to determine motives and intentions about his behavior and causes (Luthans, 2005). This theory refers to how to explain the cause of the behavior of another person or himself that will be determined whether internal such as traits, personalities and characters or external such as a situation or a certain situation that forces him to do a certain act (Luthans, 2005).
A person will form an idea about another person and the surrounding situation that causes behavior in social perception called dispositional attributions and situational attributions (Luthans, 2005). Dispositional attributions or internal causes that refer to aspects of individual behavior that exist in the self such as personality, self-perception, ability and motivation. While situational attributions or external causes that refer to the surrounding environment that can affect behavior, such as social conditions, social values, and the views of the community. In other words, any action or idea to be taken will be influenced by the internal and external factors of the individual.

\section{HYPOTHESES}

Based on the formulation of the problem and the frame of thought that has been put forward, the hypotheses proposed are as follows:

1. Organizational culture affects the performance of employees at the Office of the Ministry of Religious Affairs in South Sulawesi Province.

2. Leadership style affects the performance of employees at the Office of the Ministry of Religious Affairs of South Sulawesi Province.

3. Work Motivation affects the performance of employees at the Office of the Ministry of Religious Affairs of South Sulawesi Province.

4. Organizational Culture affects the Development of Human Resources at the Office of the Ministry of Religious Affairs of South Sulawesi Province.

5. Leadership style affects human resource development at the Office of the Ministry of Religious Affairs of South Sulawesi Province.

6. Work Motivation affects the Development of Human Resources at the Office of the Ministry of Religious Affairs of South Sulawesi Province.

7. Organizational Culture affects Performance Through Human Resource Development at the Office of the 
Musmulyadi et.al. Influence of organizational culture, leadership style and work motivation on human resource development and employee performance at the office of the ministry of religious affairs of South Sulawesi Province.

Ministry of Religious Affairs in South Sulawesi Province.

8. Leadership Style affects Performance Through Human Resource Development at the Office of the Ministry of Religious Affairs of South Sulawesi Province.

9. Work Motivation affects Performance Through Human Resource Development at the Office of the Ministry of Religious Affairs in South Sulawesi Province.

10. Human Resource Development affects Employee Performance at the Office of the Ministry of Religious Affairs of South Sulawesi Province

\section{RESEARCH METHODS}

The research approach used is to use a causal comparative quantitative method that seeks the influence of a variable with other variables. Quantitative data is data in the form of numbers or qualitative data that is guessed (Sugiyono, 2018, p. 7). This type of research uses a survey approach that is asked, collected from the entire population. The research was conducted at the Office of the Ministry of Religious Affairs in South Sulawesi Province. The types and data sources used in this study are primary and secondary data types. The data collection methods used in this study is observations, questionnaires, interviews, and documentation. The number of samples in this study was 386 from 10,293 employees consisting of 24 Offices of the Ministry of Religion and 1 Regional Office of the Ministry of Religion. Sample withdrawal is done by using cluster Random Sampling technique first to group the population into four zones, then after grouping it is used proportional random sampling technique to proportionate the sample. This research data was processed using Structural Equation Model (SEM) Analysis Moment of Structure (AMOS).

\section{RESEARCH RESULTS}

Significance Test Recap Results
\begin{tabular}{|l|l|l|l|l|l|l|}
\hline Exogenous & Endogenous & Path Coefficients & S.E. & C.R & P-Value & Ket. \\
\hline Culture Organization & Human Resources Development & 0.350 & 0.148 & 2,365 & 0.019 & Significant \\
\hline Leadership Style & Human Resources Development & 0.244 & 0.121 & 2.017 & 0.045 & Significant \\
\hline Work Motivation & Human Resources Development & 0.318 & 0.103 & 3.087 & 0.002 & Significant \\
\hline Organizational Culture & Performance & 0.151 & 0.133 & 1.135 & 0.257 & Inignificant \\
\hline Leadership Style & Performance & 0.335 & 0.106 & 3.160 & 0.002 & Significant \\
\hline Work Motivation & Performance & 0.308 & 0.112 & 2.750 & 0.006 & Significant \\
\hline Human Resources Development & Performance & 0.400 & 0.119 & 3.670 & 0.000 & Significant \\
\hline
\end{tabular}

is obtained:

Based on the table above, the result

(1). Value $\mathrm{P}$ value The influence of cultural variables on the development of human resources is significant by 0.19 with a positive marked cr of 2,365. Therefore, the value of $\mathrm{P}$ value obtained $>0.05$ and cr marked positively $>1,967$ then Ho rejected and concluded that the organizational cultural variables have a positive and significant effect on the development of human resources, the better the culture of the organization, the better the development of human resources and vice versa.

(2).P value The variable influence of leadership style on human resources development is significant at 0.45 with a positive marked $\mathrm{cr}$ of 2,017. Therefore, the value of $\mathrm{P}$ value obtained $>0.05$ and cr marked positively $>1,967$ then $\mathrm{Ho}$ rejected and concluded that the variable leadership style has a positive and significant effect on human resources development, the better the leadership style, the better the development of HUMAN RESOURCES and vice versa.

(3). Value P value The influence of variable work motivation on human resources development is insignificant by 0.02 with a positive marked $\mathrm{cr}$ of 3,086 . Therefore, the value of $\mathrm{P}$ value obtained $<0.05$ and $\mathrm{cr}$ marked positive $>1,967$ then Ho rejected and concluded that the 
Musmulyadi et.al. Influence of organizational culture, leadership style and work motivation on human resource development and employee performance at the office of the ministry of religious affairs of South Sulawesi Province.

variable of work motivation has a positive and significant effect on the development of human resources, the better the work motivation, the better the development of human resources and vice versa.

(4). Value $P$ value Influence of cultural variables on significant performance of 0.257 with negative marked cr of 1.135 . Therefore the $\mathrm{P}$ value obtained $>0.05$ and cr marked negative $<1,967$ then Ho is not rejected and concluded that the organizational cultural variables have a negative and insignificant effect on performance.

(5). $P$ value The influence of leadership style variable on insignificant performance is 0.02 with a positive marked $\mathrm{cr}$ of 3,161 . Therefore, the value of $\mathrm{P}$ value obtained $<0.05$ and cr marked positive >1,967 then Ho rejected and concluded that the variable leadership style has a significant positive effect on performance, the better the leadership style, the better the performance of employees and vice versa.
(6).P value The influence of work motivation variable on performance is significant at 0.06 with a positive marked cr of 2,750. Therefore, the value of $\mathrm{P}$ value obtained $>0.05$ and cr marked positive $>1,967$ then Ho rejected and concluded that the variable of work motivation has a significant positive effect on performance, the higher the work motivation, the better the employee's performance and vice versa.

(7). $P$ value The variable impact of $\mathrm{HR}$ development on performance is significant $(* * *)$ with a positive marked $\mathrm{cr}$ of 3,670. Therefore the value of $\mathrm{P}$ value obtained > 0.05 and cr marked positive >1,967 then Ho rejected and concluded that the variable of human resources development has a very significant positive effect on performance, the better the development of human resources, the better the performance of employees and vice versa.

Sobel Test Result Recap Table

\begin{tabular}{|l|l|l|l|l|l|l|l|}
\hline Exogenous & Mediation & Endogenous & $\begin{array}{l}\text { Indirect } \\
\text { Coefficient }\end{array}$ & S.E. & $\begin{array}{l}\text { T } \\
\text { Statistics }\end{array}$ & $\begin{array}{l}\text { P } \\
\text { Value }\end{array}$ & Ket. \\
\hline $\begin{array}{l}\text { Culture } \\
\text { Organization }\end{array}$ & $\begin{array}{l}\text { Human Resources } \\
\text { Development Performance }\end{array}$ & Performance & 0,149 & 0,072 & 2,058 & 0,041 & Significant Mediating \\
\hline Leadership Style & $\begin{array}{l}\text { Human Resources } \\
\text { Development Performance }\end{array}$ & Performance & 0,188 & 0,056 & 3,361 & 0,001 & Significant Mediating \\
\hline $\begin{array}{l}\text { Work Resources } \\
\text { Motivation }\end{array}$ & $\begin{array}{l}\text { Human Performance } \\
\text { Development Performance }\end{array}$ & 0,127 & 0,056 & 2,262 & 0,025 & Significant Mediating \\
\hline
\end{tabular}

(1). The significant value of human resources development variable mediation test on the influence of organizational culture on performance is 0.041 , therefore the significant value obtained by $>0.05$ is concluded that significantly the $\mathrm{hr}$ development variable can mediate the direct influence of organizational cultural variables on performance. Leadership variables can directly affect performance through $\mathrm{hr}$ development variables. A good organizational culture will improve human resources development which will further improve employee performance, and vice versa.
(2). The significant value of human resources development variable mediation test on the influence of leadership style on performance is 0.01 , therefore the significant value obtained $<0.05$ it is concluded that significantly $\mathrm{hr}$ development variables can mediate the indirect influence of leadership style variables on performance. Leadership style variables can have an indirect effect on performance through $\mathrm{hr}$ development variables. Good leadership will improve employee human resources which will further improve employee performance, and vice versa. 
Musmulyadi et.al. Influence of organizational culture, leadership style and work motivation on human resource development and employee performance at the office of the ministry of religious affairs of South Sulawesi Province.

(3). The significant value of human resources development variable mediation test on the influence of work motivation on performance is 0.025 , therefore the significant value obtained by $<0.05$ is concluded that significantly $\mathrm{hr}$ development variables can mediate the indirect influence of work motivation variables on performance. Work motivation variables can have an indirect effect on performance through hr development variables. High work motivation will improve the development of human resources which will further improve employee performance, and vice versa.

\section{CONCLUSION}

Based on the results of the analysis and discussion that has been presented in the previous chapter, it can be drawn some conclusions that the variables of leadership style, work motivation, and human resources development have a positive and significant effect on performance. However, this is in contrast to organizational cultural variables that have no significant impact on performance. Then the organizational culture, leadership style, and work motivation have a positive and significant effect on human resources development. Furthermore, if the development of human resources is used as an intervening variable to performance then the results obtained show that the culture of the organization through the development of human resources has a significant impact on employee performance. Then leadership style through human resources development has a significant impact on employee performance. Terakir Work motivation through human resources development also has a significant impact on employee performance.

Based on the research can be concluded that the leadership style run by a leader in this case the Ministry of Religious Affairs of South Sulawesi greatly affects the performance produced by employees. Work motivation is one of the things needed in an organization, in this study it can be seen that work motivation is needed at the Ministry of Religious Affairs of South Sulawesi because it greatly affects the performance of employees. However, for organizational cultural variables in this study it was obtained that the culture of an organization does not determine or does not have a significant influence on the performance of employees.

Furthermore, in this study it was also obtained that organizational culture, leadership style, and work motivation have a significant influence on human resources development. It shows that in doing human resources development also need to pay attention to the culture embraced by the organization and adjust it to the leadership style in the organization, then in doing human resources development motivation is needed by employees to improve the quality of their human resources.

For the development of human resources that are used as intervening variables can also be concluded that the first culture of the organization through the process of human resources development can improve the performance of employees, then the leadership style embraced by the organization through the development of human resources can improve employee performance. Furthermore, the work motivation provided through the development of human resources is also very influential to improve employee performance.

\section{ADVICE}

Based on the conclusions of the research results that have been outlined, then here are some suggestions that researchers can give:

1. Variabe organizational culture should be a special concern for the Ministry of Religious Affairs of South Sulawesi, because the culture of the organization should be one of the supports for the organization in improving the performance of its employees.

Organization leaders must maintain their 
Musmulyadi et.al. Influence of organizational culture, leadership style and work motivation on human resource development and employee performance at the office of the ministry of religious affairs of South Sulawesi Province.

relationship with employees or members so that employees will also better maintain the quality of their work so as to improve employee performance.

2. Human resources development is needed by the Ministry of Religious Affairs of South Sulawesi as a form of efforts to improve the performance of employees so that the purpose of organizing

\section{Acknowledgement: None}

\section{Conflict of Interest: None}

\section{Source of Funding: None}

\section{REFERENCES}

1. Ayuningtyas, Yulian, H., \& Pamudji, S. (2012). Pengaruh Pengalaman Kerja, Independensi, Obyektifitas, Integritas dan Kompetensi Terhadap Kualitas Hasil Audit . Dipenogoro Journal Of Accounting, 22822310.

2. Dafruddin, \& Heryanto. (2019). The Effect of Work Motivation and Work Environment on Performance With Satisfaction as intervening Variabels Education Personne Rektorate Andalas Universityl . Archives Of Business Research, 103-120.

3. Dio, R., \& Hamid, D. (2017). Pengaruh Gaya Kepemimpinan Terhadap Kinerja Karyawan ( Studi Pada Karyawan Divisi Human Resources Management Compensation and Benefits PT Freeport Indonesi). Jurnal Administrasi Bisnis, 1-11.

4. Elbadiansyah. (2019). Manajemen Sumber Daya Manusia. Malang: CV IRDH.

5. Lapisa, I., Kariza, I., \& Aramina, D. (2015). The Role of Organizational Culture in University Quality Management. International Scientific Conference Economic and Management Conference, 770-774.
6. Luthans. (2005). Pengaruh Pengalaman Kerja, Objektivitas, Integritas dan Kompetensi Terhadap Kualitas Audit Aparat Pengawasan Intern Pemerintahan (Apip) dengan Etika Auditor Sebagai Variabel Moderasi. Accountia, 200-2016.

7. meutia, T. (2017). Pengaruh Budaya Organisasi, Gaya Kepemimpinan dan Motivasi Kerja Terhadap Kinerja Karyawan Pada PT. PLN (persero) Wilayah I Aceh. Jurnal Perekonomian dan Akuntansi, 113123.

8. Mochlas, M. (2017). analysis Of Organizational Culture Company South Korea In Indonesia. International Journal Of Business and Management Studies, 66-74.

9. Nazwirman. (2019). Analysis of Employee Performance; A Case Study in Port Corporation. Jurnal Organisasi dan Manajemen, 24-35.

10. Robbins, S. (2003). Organizational Behavior. New Jersey: Prentice Hall International Inc.

11. Sugiyono. (2018). Statistik Untuk Penelitian. Bandung: Alphabeta.

12. Sutrisno, E. (2018). Budaya Organisasi. Jakarta: Prenamedia Group.

13. Triandis. (1971). Pengaruh Independensi Pengalaman Kerja, Obyektifitas, Integritas dan Kompetensi Terhadap Kualitas Audit (Studi Pada Auditor Inspektorat Kota/Kab. di Jawa Tengah. Dipenogoro Journal of Accounting, 1-10.

How to cite this article: Musmulyadi, Mus AR, Sinring B et.al. Influence of organizational culture, leadership style and work motivation on human resource development and employee performance at the office of the ministry of religious affairs of South Sulawesi Province. International Journal of Research and Review. 2021; 8(4): 171-179. DOI: https://doi.org/ 10.52403/ijrr.20210423 